\title{
Rapid regulation of phosphate uptake in freshwater cyanobacterial blooms
}

\author{
Luis Aubriot*, Sylvia Bonilla \\ Phytoplankton Ecology and Physiology Group, Sección Limnología, Facultad de Ciencias, Universidad de la República, \\ Iguá 4225, Montevideo 11400, Uruguay
}

\begin{abstract}
Cyanobacterial blooms are generally explained by nutrient uptake kinetic constants that may confer competitive capabilities, like high nutrient-uptake rate, affinity, and storage capacity. However, cyanobacteria are capable of flexible physiological responses to environmental nutrient fluctuations through adaptation of their phosphate uptake properties. Growth optimization is possible if the physiological reaction time of cyanobacteria $\left(t_{R}\right)$ matches the duration of nutrient availability. Here, we investigate the $t_{\mathrm{R}}$ of this complex physiological process. We performed $\left[{ }^{32} \mathrm{P}\right]$ uptake experiments with filamentous cyanobacterial blooms. The phytoplankton were subjected to different nutrient exposure times $\left(t_{\mathrm{E}}\right)$ by varying patterns of phosphate additions. After 15 to 25 min of phosphate $t_{\mathrm{E}}$, the cyanobacteria-dominated phytoplankton began their adaptive response by reducing and finally ceasing uptake activity before exhausting their nutrient uptake capacity. The time of onset of phosphate uptake regulation (in min) is an indicator of $t_{\mathrm{R}}$. Rapid adaptive behaviour may be the initial phase of longer-term nutrient acclimation (hours to days), which results in a higher growth rate. The growth response of bloom-forming cyanobacteria may be more dependent on the ability to optimize the uptake of phosphate during the time span of nutrient fluctuation than on the amount of nutrient taken up per se. Freshwater cyanobacterial blooms may therefore be promoted by their short $t_{\mathrm{R}}$ during phosphate fluctuations.
\end{abstract}

KEY WORDS: Physiological adaptation • Physiological reaction time • Phosphate uptake • Cyanobacteria $\cdot$ Growth optimization $\cdot$ Phytoplankton · Environmental fluctuations

\section{INTRODUCTION}

Cyanobacterial blooms are frequently stable and resilient in lakes (Scheffer et al. 1997, Bonilla et al. 2012), even after dissolved nutrient depletion (Catherine et al. 2008). Cyanobacterial dominance is generally explained by competitive advantages in exploiting low phosphate concentrations, including high affinity and maximum velocity of cellular uptake systems, and by high nutrient storage capacity (Istvánovics et al. 2000, Moutin et al. 2002, Antenucci et al. 2005, Burford \& O'Donohue 2006, Casey et al. 2009, Posselt et al. 2009). These advantages are based on the assumption that phytoplankters have species-specific uptake properties definable with kinetic constants like the half saturation constant, maximum uptake velocity and specific affinity (e.g. Vadstein \& Olsen 1989, Tanaka et al. 2004, Tambi et al. 2009). However, other studies have addressed the complex features of phosphate uptake regulation by cyanobacteria. These organisms sense phosphate availability in the environment by histidine kinases and response regulators, which induce the expression of Pho regulon genes that encode high affinity P-binding proteins, alkaline phosphatase and other relevant proteins (Suzuki et al. 2004, Schwarz \& Forchhammer 2005, Juntarajumnong et al. 2007, Orchard et al. 2009, Pitt et al. 2010). Additional complexities in phosphate regulation are related to changes in the 
kinetics and energetics of uptake systems during responses to sudden phosphate fluctuations (Falkner et al. 1995, Wagner et al. 1995, Falkner \& Falkner 2003, Falkner et al. 2006, Aubriot et al. 2011). When phosphate is available, the external nutrient is removed by phytoplankton down to low nanomolar threshold values $\left(\left[\mathrm{P}_{\mathrm{e}}\right]_{\mathrm{A}}\right)$, below which incorporation is not energetically possible (Falkner et al. 1989, 1994). Phosphate uptake takes place only if the external concentration surpasses the threshold value (Rigler 1956, Falkner et al. 1989, Aubriot et al. 2000). Adaptive kinetic responses are characterised by alterations in threshold values and uptake rates, which reflect adjustments of cellular energy conversion (Falkner et al. 1989, 1993).

Molecular processes in which the Pho regulon expression is involved are accompanied by membrane processes that affect the functional organisation of proteins. For this reason, it is not appropriate to employ the Michaelis kinetic model based on a particular enzyme description (Falkner et al. 1995, Button 1998, Bonachela et al. 2011). This model is valid for initial velocities and predicts uptake to stop at zero substrate concentration, therefore not accounting for the existence of a (variable) threshold value (Falkner et al. 1995). Alternatively, phosphate uptake can be analyzed with a theoretically and experimentally validated proportional flowforce relationship (Thellier 1970, Falkner et al. 1989). This model is flexible because it considers the following variable physiological parameters that are altered in response to external conditions: the membrane conductivity coefficient, $L_{\mathrm{P}}$, which is proportional to the maximum velocity of the uptake process, and the threshold phosphate concentration $\left[\mathrm{P}_{\mathrm{e}}\right]_{\mathrm{A}}$ (Falkner et al. 1989, 1994). The flow-force model takes a more realistic approach because it allows investigation of the time course of flexible phosphate uptake behaviour of phytoplankton in fluctuating environments.

Cyanobacteria growth optimisation is related to rapid adaptive responses in fluctuating environments. For this optimisation to occur, the timescale of the physiological response of cyanobacteria (reaction time $\left[t_{R}\right]$ ) must match the duration of transient environmental nutrient fluctuations (exposure time $\left[t_{\mathrm{E}}\right]$ ) (Stomp et al. 2008, Aubriot et al. 2011). Accordingly, a recent study showed that cyanobacteria-dominated phytoplankton respond to phosphate $t_{\mathrm{E}}$ by a physiological adaptation in which organisms reduce the uptake rate and increase the threshold value toward an energetically favourable state (Aubriot et al. 2011). The minimum $t_{\mathrm{E}}$ required to provoke a signifi- cant alteration in phosphate uptake properties $\left(L_{\mathrm{P}}\right.$ and $\left[\mathrm{P}_{\mathrm{e}}\right]_{\mathrm{A}}$ ) can be considered an indicator of $t_{\mathrm{R}}$. The $t_{\mathrm{R}}$ to transient phosphate availability is crucial for understanding the effect of short-term nutrient fluctuations on cyanobacterial growth under apparently suboptimal conditions. However, the $t_{\mathrm{R}}$ of cyanobacterial populations to available phosphate is still an undefined subject.

In the present study, we investigated the $t_{\mathrm{R}}$ of adaptive phosphate uptake behaviour of cyanobacteria-dominated phytoplankton in response to phosphate fluctuations and the role of $t_{\mathrm{R}}$ in cyanobacterial blooms. The analysis of a wide range of $t_{\mathrm{E}}$ and the effect on phosphate uptake parameters allows the identification of the $t_{\mathrm{R}}$ of phytoplankton as the onset of an adaptive response. We performed $\left[{ }^{32} \mathrm{P}\right]$ uptake experiments with a planktonic community from a eutrophic lake composed mainly of filamentous cyanobacteria. The community was subjected to different patterns of phosphate additions in order to produce increasing nutrient $t_{\mathrm{E}}$ from minutes to several hours but with the same amount of added phosphate. The results are discussed in terms of how the short $t_{\mathrm{R}}$ of phosphate uptake regulation by bloom-forming cyanobacteria may allow for rapid growth optimisation in fluctuating environments.

\section{MATERIALS AND METHODS}

\section{Study area}

Six experiments (A to F) were performed during summer and autumn (December to May) of 2004, 2006 and 2007, with water samples from Lago Rodó, a shallow (1.5 m mean depth) hypereutrophic urban lake in Montevideo, Uruguay (Aubriot et al. 2000). The water column was characterised by in situ measurements of photosynthetically available radiation (PAR) (using a LI-192SA $4 \pi$ quantum sensor recorded with a LI-250 LI-COR datalogger) to calculate the light extinction coefficient $\left(K_{\mathrm{d}}, \mathrm{m}^{-1}\right)$ as well as of temperature, dissolved oxygen and $\mathrm{pH}$ (Horiba D-25). Subsurface samples of 2 to 51 were taken with dark bottles and immediately transported to the laboratory (within ca. $30 \mathrm{~min}$ ). Samples were processed by filtering $200 \mathrm{ml}$ aliquots through Whatman glass fibre filters (GF/F) pre-soaked in ultrapure water. The unfiltered sample, the filtrate and the filter with the particulate material were stored at $-20^{\circ} \mathrm{C}$ for analyses of total and dissolved nutrients and chlorophyll a (chl a). 


\section{Spectrophotometric determinations}

Orthophosphate and dissolved inorganic nitrogen (DIN) were analyzed following Strickland \& Parsons (1972). Total phosphorus (TP) and total nitrogen (TN) concentrations were determined after persulfate oxidation according to Valderrama (1981). Chl a extraction was quantified according to Nusch (1980). below) for the alteration of phosphate uptake parameters. To achieve a different $t_{\mathrm{E}}$, the same total $\left[{ }^{32} \mathrm{P}\right]$ labelled phosphate was applied to 2 subsamples $\left(\mathrm{S}_{1}\right.$ and $\left.\mathrm{S}_{2}\right)$ with modifications in the pulse pattern (Fig. 1). In Expt $\mathrm{A}$, the effect of short $t_{\mathrm{E}}$ was evaluated by applying 2 equal, low external phosphorus isotope $\left[{ }^{32} \mathrm{P}_{\mathrm{e}}\right]$ concentrations $(1.8 \mu \mathrm{M})$ to each subsample; the second pulse was applied 3.3 $\mathrm{h}$ after the first phosphate addition. In Expts B to D, phytoplankton were exposed to higher $t_{\mathrm{E}}$ by apply-

\section{Analysis of phytoplankton}

Phytoplankton samples were preserved with acid Lugol's solution and kept in darkness for up to 3 mo until processing. Taxonomic identification was performed with an Olympus optical microscope, using 400 to $1000 \times$ magnification, to the lowest possible taxonomic level (species or genus) or morphotype (eukaryotic phytoplankton with diameter $<5 \mu \mathrm{m}$ ). Phytoplankton was counted in random fields according to Guillard (1978), and taxa richness was calculated with rarefaction curves (Gotelli \& Colwell 2010). Calculation of population and community biovolume $\left(\mathrm{mm}^{3} \mathrm{l}^{-1}\right)$ was based on the geometric shape of organisms by using average sizes of 10 to 30 individuals per taxon (Hillebrand et al. 1999).

\section{Experimental design}

Phosphate uptake was measured in 2 identical subsamples of $50 \mathrm{ml}\left(\mathrm{S}_{1}\right.$ and $\left.\mathrm{S}_{2}\right)$ obtained from the original lake sample (Fig. 1), which were pre-filtered through $80 \mu \mathrm{m}$ mesh to remove large zooplankton. Subsamples were gently mixed with a magnetic stirrer and illuminated (150 $\mu \mathrm{mol}$ photons $\mathrm{m}^{-2} \mathrm{~s}^{-1}$ ) immediately after arrival in the laboratory. Acclimation to mean lake temperature $\left(25 \pm 1^{\circ} \mathrm{C}\right)$ was allowed $30 \mathrm{~min}$ before experiments. Phosphate deficiency was confirmed by activated phosphate influx rates and threshold values in the nanomolar range.

The experiments were designed to determine the $t_{\mathrm{R}}$ of cyanobacteria-dominated phytoplankton subjected to a wide range of $t_{\mathrm{E}}$ (see 'Data analysis'

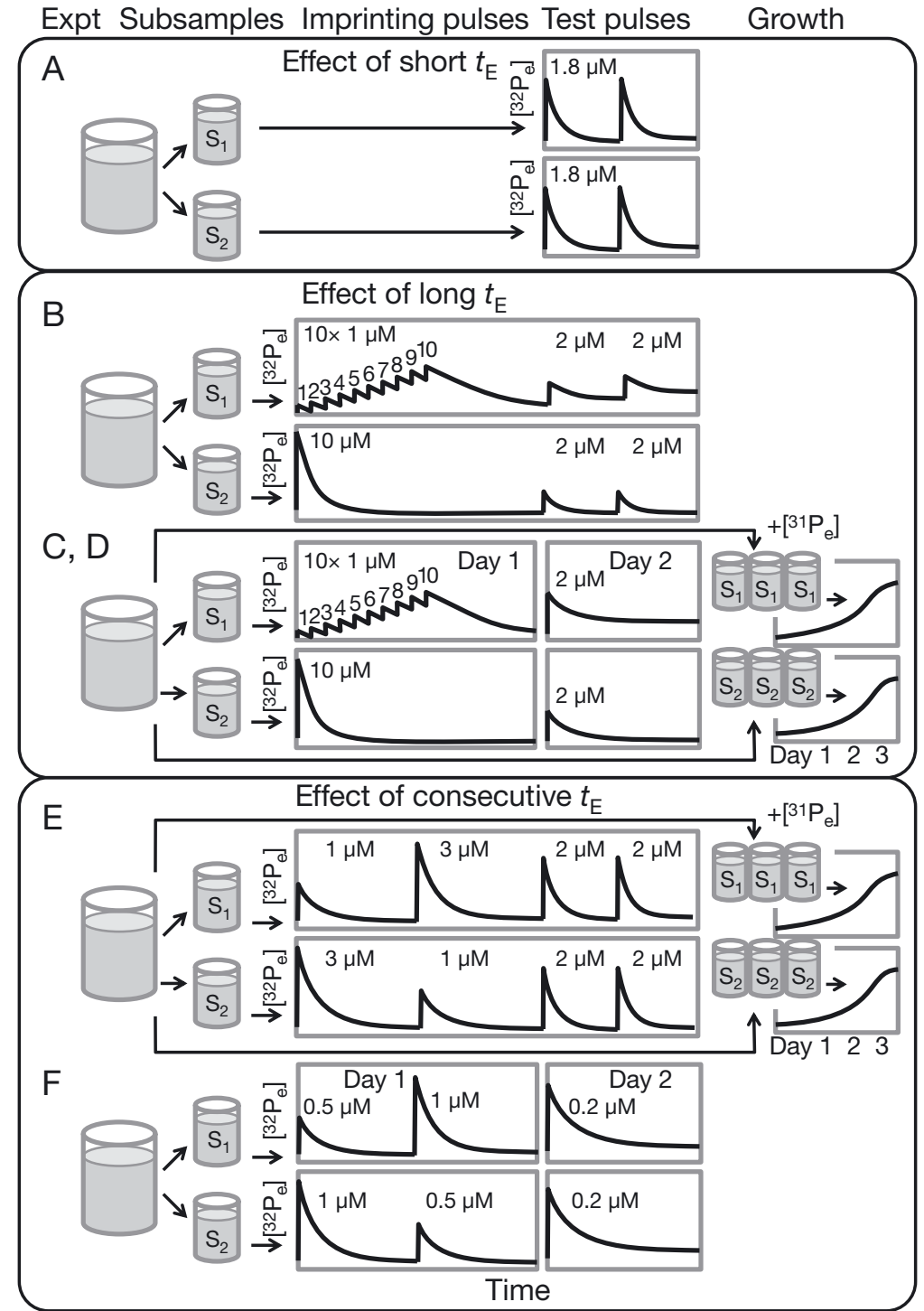

Fig. 1. Schematic experimental design. Imprinting and test $\left[{ }^{32} \mathrm{P}\right]$ pulse treatments are summarised for all experiments (A to F). The total $\left[{ }^{32} \mathrm{P}\right]$ added to subsamples $\mathrm{S}_{1}$ and $\mathrm{S}_{2}$ was the same at the end of imprinting and test procedure. The first cylinder represents the sample obtained from hypereutrophic Lake Rodó, Uruguay. Growth measurements were conducted on lake water samples for Expts $\mathrm{C}$ to $\mathrm{E}$ using non-radioactive $\mathrm{K}_{2} \mathrm{HPO}_{4}$ $\left(\left[31 \mathrm{P}_{\mathrm{e}}\right]\right)$. See 'Materials and methods' for further details. $\mathrm{P}_{\mathrm{e}}$ : external phosphorus; $t_{\mathrm{E}}$ : exposure time 
ing a sequence of 10 additions of $1 \mu \mathrm{M}$ phosphate to subsample $\mathrm{S}_{1}$, with each pulse applied every $6 \mathrm{~min}$. The same amount of phosphate $(10 \mu \mathrm{M})$ was given to $S_{2}$ in 1 addition. This 'imprinting' procedure generated different $t_{\mathrm{E}}$ values in $\mathrm{S}_{1}$ and $\mathrm{S}_{2}$ with the same amount of total phosphate (Fig. 1). To compare the resulting uptake kinetic properties between $S_{1}$ and $S_{2}$, the uptake behaviour was then analysed after applying equal phosphate concentrations to each subsample ('test pulses') (Fig. 1). The fact that equal amounts of total phosphate were applied to $S_{1}$ and $S_{2}$ excludes an interpretation of the effects as exhausting phosphate uptake capacity. In all experiments (A to F), test pulses were applied after the achievement of the $\left[\mathrm{P}_{\mathrm{e}}\right]_{\mathrm{A}}$ threshold value of the imprinting treatment. i.e. at constant/asymptotic external phosphate concentration. Expts C and D were designed to show the long-term effects of imprinting $t_{\mathrm{E}}$, by applying 1 test pulse of $2 \mu \mathrm{M}$ phosphate after approx. $17 \mathrm{~h}$.

Expts $\mathrm{E}$ and $\mathrm{F}$ were designed to examine how consecutive $t_{\mathrm{E}}$ result in the progressive adaptive response (Fig. 1). The same amount of phosphate was applied by giving a smaller and greater imprinting pulse to each subsample but added in reverse temporal order as follows: in $\mathrm{S}_{1}$, the smaller phosphate pulse was added first, then the greater amount, and vice versa in $\mathrm{S}_{2}$ (i.e. 1 and $3 \mu \mathrm{M}$ in Expt $\mathrm{E}$ and 0.5 and $1 \mu \mathrm{M}$ in Expt F). In all experiments, test pulses were applied after the achievement of $\left[\mathrm{P}_{\mathrm{e}}\right]_{\mathrm{A}} ; 2$ test pulses of $2 \mu \mathrm{M}$ phosphate each in Expt E and 1 test pulse of $0.2 \mu \mathrm{M}$ at $24 \mathrm{~h}$ after the beginning of imprinting treatment in Expt F.

\section{Measurement of phosphate uptake}

Net phosphate uptake was measured using micromolar [ $\left.{ }^{32} \mathrm{P}\right]$ (Aubriot et al. 2000). Phosphate removal by phytoplankton was measured in 0.8 to $1.5 \mathrm{ml}$ aliquots filtered through Millipore HA filters (0.45 $\mu \mathrm{m}$ pore size) and following a time sequence of $0.5,2,5,10,15,20$ and $35 \mathrm{~min}$, then every 20 to $30 \mathrm{~min}$, as indicated in the figures. Each sampling time point and lags were timed $\left(\begin{array}{lll} \pm 2 & \mathrm{~s}\end{array}\right)$. The absence of prokaryotic cell interference in the filtrate was previously tested by Aubriot et al. (2011). Our study integrated phosphate removal by phytoplanktonic prokaryotes, eukaryotes and bacterioplankton. The radioactivity in the filtrate was measured in water using a Beckman liquid scintillation counter (LS 6000). The detection limit of this method is $1 \mathrm{nM}$ phosphate.

\section{Measurement of growth rate}

Samples for growth experiments were obtained from the same original lake samples used for chemical analyses and uptake experiments (Fig. 1). Subsamples were acclimated and processed as indicated in 'Experimental design'. Growth rates were evaluated on 4 occasions (26 February 2004; 30 March 2004; data not shown; 16 March 2004; and 6 February 2007) and run in parallel to the corresponding $\left[{ }^{32} \mathrm{P}\right]$ uptake experiments. The imprinting and test phosphate pulse treatments described in Expts C, D and $E$ were replicated in triplet subsamples of $350 \mathrm{ml}$ each but using non-radioactive $\mathrm{K}_{2} \mathrm{HPO}_{4}\left(\left[{ }^{31} \mathrm{P}_{\mathrm{e}}\right]\right)$. A blank subsample incubation (in triplet) was used as a control. Replicates were gently bubbled with humidified (Milli-Q water) pre-filtered (GF/F sterilised) air and incubated at the same light and temperature conditions as in the uptake experiments. Growth rate was evaluated by measuring optical density (at $750 \mathrm{~nm}$ ) twice a day. Chl a concentration was determined in each subsample at the beginning and end of incubation.

\section{Theoretical considerations}

The dependence of net uptake rates on external phosphate concentration is assessed by a relationship between the uptake rate, $J_{\mathrm{P}}$ (given in $\mu \mathrm{mol}$ internal $\mathrm{P} \mathrm{mg}^{-1} \mathrm{chl} \mathrm{a} \mathrm{h}^{-1}$ ), and the driving force of this process (Thellier 1970, Falkner et al. 1989), expressed as follows:

$$
J_{\mathrm{p}=}-\mathrm{d}\left[\mathrm{P}_{\mathrm{e}}\right] / \mathrm{dt}=L_{\mathrm{P}}\left(\log \left[\mathrm{P}_{\mathrm{e}}\right]-\log \left[\mathrm{P}_{\mathrm{e}}\right]_{\mathrm{A}}\right)
$$

where $\left[\mathrm{P}_{\mathrm{e}}\right]$ is the external phosphate concentration, $L_{\mathrm{P}}$ is a conductivity coefficient proportional to the maximum uptake velocity (Falkner et al. 1994, 1995), and $\left[\mathrm{P}_{\mathrm{e}}\right]_{\mathrm{A}}$ is the threshold concentration at which uptake ceases due to energetic reasons (Falkner et al. 1989, 1994).

The linearity of the flow-force relation can be lost in the transient adaptive operation mode of uptake systems (Falkner et al. 2006, Aubriot et al. 2011). Under these conditions, uptake behaviour during the self-organisation process can be modelled when nonlinear terms are added to Eq. (1), leading to the following relation (Thellier 1970):

$$
\begin{gathered}
J_{\mathrm{p}=}-\mathrm{d}\left[\mathrm{P}_{\mathrm{e}}\right] / \mathrm{dt}=L_{\mathrm{P}}\left(\log \left[\mathrm{P}_{\mathrm{e}}\right]-\log \left[\mathrm{P}_{\mathrm{e}}\right]_{\mathrm{A}}\right) \\
+L\left(\log \left[\mathrm{P}_{\mathrm{e}}\right]-\log \left[\mathrm{P}_{\mathrm{e}}\right]_{\mathrm{A}}\right)^{m}
\end{gathered}
$$

where $m>1$; $m$ characterises (in addition to conductivity coefficients $L$ and $L_{\mathrm{P}}$ ) the dependence of the 
phosphate influx rate on the driving force during an adaptive process (Falkner et al. 2006). A satisfactory fit $\left(r^{2} \geq 0.9\right)$ was found for either $m=3$ or 5 (see Table 2). A more detailed theoretical explanation is found elsewhere (Falkner et al. 1995, Wagner et al. 1995, Aubriot et al. 2011).

\section{Data analysis}

The flow-force relationships were fitted using MLAB (Mathematical Modelling System, Civilized Software) and following Falkner et al. (2006) and Aubriot et al. (2011). The replot of $J_{\mathrm{P}}$ versus $\log \left[\mathrm{P}_{\mathrm{e}}\right]$ was performed according to Thellier (1970) (Thellier plot), in which the slope corresponds to $L_{\mathrm{P}}$ expressed in $\mu \mathrm{mol}$ internal $\mathrm{P} \mathrm{mg}^{-1} \mathrm{chl} \mathrm{a}^{-1}$ (Wagner et al. 1995).

The $t_{\mathrm{E}}$ is defined as the period of time between $\left[{ }^{32} \mathrm{P}_{\mathrm{e}}\right]$ phosphate addition and the moment at which $\left[\mathrm{P}_{\mathrm{e}}\right]_{\mathrm{A}}$ is attained (when $99 \%$ of the added $\left[{ }^{32} \mathrm{P}_{\mathrm{e}}\right]$ phosphate is incorporated by phytoplankton after a pulse). The cumulative $t_{\mathrm{E}}\left(\sum t_{\mathrm{E}}\right)$ is the sum of $t_{\mathrm{E}}$ values determined in each phosphate pulse. $t_{\mathrm{R}}$ is the minimum $t_{\mathrm{E}}$ required to provoke a significant alteration in the phosphate uptake properties $L_{\mathrm{P}}$ and $\left[\mathrm{P}_{\mathrm{e}}\right]_{\mathrm{A}} \cdot\left[\mathrm{P}_{\mathrm{e}}\right]_{\mathrm{A}}$ increase was calculated as the amount of change from the $\left[\mathrm{P}_{\mathrm{e}}\right]_{\mathrm{A}}$ of 1 pulse to the $\left[\mathrm{P}_{\mathrm{e}}\right]_{\mathrm{A}}$ obtained after the next phosphate addition.

The reliability of the method has been validated previously (Aubriot et al. 2000, 2011). Significant differences of $\left[\mathrm{P}_{\mathrm{e}}\right]_{\mathrm{A}}$ between subsamples were determined due to a lack of overlap of the $95 \%$ confidence intervals $\left(\mathrm{CI}_{95} \%\right.$ calculated from the flow-force fitting of each time course of phosphate removal. $L_{\mathrm{P}}$ and growth rate differences among treatments were tested with a general linear model combined with analysis of covariance (GLM-ANCOVA) and Kruskal-Wallis 1-way analysis of variance, respectively (Statistica 6.0, StatSoft).

\section{RESULTS}

\section{Lake conditions and phytoplankton community}

Lake temperature did not exhibit large variations among summer samplings $\left(25.2 \pm 1.9^{\circ} \mathrm{C}\right)$, except in Expt F (performed in autumn) (Table 1). The water column was always mixed, and the euphotic zone covered almost the entire depth $\left(K_{\mathrm{d}}=6.2 \pm 2.0 \mathrm{~m}^{-1}\right)$. Dissolved oxygen was lower at the lake bottom $\left(13.2 \pm 5.6\right.$ and $5.1 \pm 3.4 \mathrm{mg} \mathrm{l}^{-1}$ at the surface and bottom, respectively). The orthophosphate concentration was below the limit of spectrophotometric detection $(<0.3 \mu \mathrm{M})$, except in Expt E $(0.6 \mu \mathrm{M})$. DIN values were high and variable $(27.3 \pm 17.8 \mu \mathrm{M})$ and consisted of up to $53 \%$ nitrate. Low nitrate concentrations were determined at the end of the study period $(<7.1 \mu \mathrm{M})$. The mean TP concentration was $6.2 \pm 1.3 \mu \mathrm{M}$, and the concentration of $\mathrm{TN}$ varied between 130.5 and $308.2 \mu \mathrm{M}$. The chl a concentration ranged from $107.8 \pm 4.4 \mathrm{\mu g} \mathrm{l}^{-1}$ at the end of the study (Expt F) to the highest value of $411.6 \pm 9.8 \mu \mathrm{g} \mathrm{l}^{-1}$ on the sampling date of Expt D (Table 1).

The highest number of taxa belonged to cyanobacteria, followed by diatoms, cryptophytes, euglenophytes, dinoflagellates and chlorophytes (Fig. 2). The high phytoplankton biomass is indicated by the chl $a$ and biovolume values (chl a: $>100 \mathrm{\mu g} \mathrm{l}^{-1}$; biovolume: 27 to $130 \mathrm{~mm}^{3} \mathrm{l}^{-1}$ ). Filamentous cyanobacteria were the dominant group ( $>83 \%$ of total biovolume) in all samplings, consisting of Planktothrix agardhii, Raphidiopsis mediterranea and Planktolyngbya sp. (Fig. 2).

\section{Influence of increasing phosphate $t_{\mathrm{E}}$ on uptake parameters}

A short $t_{\mathrm{E}}$ of 15 to 24 min was obtained after 2 consecutive phosphate pulses, which resulted in practi-

Table 1. Physicochemical characteristics of Lago Rodó at each corresponding sampling date. Expt: experiment; T: water temperature; DO: dissolved oxygen at surface and bottom, respectively; TN: total nitrogen; TP: total phosphorus; Chl a: chlorophyll $a_{i}-$ : below detection limits of standard methods $\left(\mathrm{NH}_{4}{ }^{+}: 0.7 \mu \mathrm{M} \mathrm{N} ; \mathrm{NO}_{2}^{-}: 0.2 \mu \mathrm{M} \mathrm{N}_{i} \mathrm{NO}_{3}{ }^{-}: 7.1 \mu \mathrm{M} \mathrm{N}_{i} \mathrm{PO}_{4}{ }^{3-}: 0.3 \mu \mathrm{M}\right.$ P; TN: $7.1 \mu \mathrm{M} \mathrm{N}$; TP: $0.3 \mu \mathrm{M} \mathrm{P}$; chl a: $0.1 \mu \mathrm{g} \mathrm{l}^{-1}$ )

\begin{tabular}{|c|c|c|c|c|c|c|c|c|c|c|}
\hline Expt & $\begin{array}{c}\text { Date } \\
\text { (d.mo.yr) }\end{array}$ & $\begin{array}{c}T \\
\left({ }^{\circ} \mathrm{C}\right)\end{array}$ & $\begin{array}{c}\mathrm{DO} \\
\left(\mathrm{mg} \mathrm{l}^{-1}\right)\end{array}$ & $\begin{array}{c}\mathrm{NH}_{4}^{+} \\
(\mu \mathrm{M} \mathrm{N})\end{array}$ & $\begin{array}{c}\mathrm{NO}_{2}^{-} \\
(\mu \mathrm{M} \mathrm{N})\end{array}$ & $\begin{array}{c}\mathrm{NO}_{3}^{-} \\
(\mu \mathrm{M} \mathrm{N})\end{array}$ & $\begin{array}{c}\mathrm{PO}_{4}{ }^{3-} \\
(\mu \mathrm{M} \mathrm{P})\end{array}$ & $\begin{array}{c}\text { TN } \\
(\mu \mathrm{M} \mathrm{N})\end{array}$ & $\begin{array}{c}\text { TP } \\
(\mu \mathrm{M} P)\end{array}$ & $\begin{array}{c}\text { Chl a } \\
\left(\mu \mathrm{g} \mathrm{l}^{-1}\right)\end{array}$ \\
\hline A & 11.01 .06 & 24.0 & $9.3-6.7$ & 2.1 & 3.8 & 43.2 & - & 308.2 & 6.2 & $240.3 \pm 1.0$ \\
\hline B & 29.01 .04 & 26.8 & $10.0-1.0$ & 2.2 & 1.4 & 38.5 & - & 130.5 & 4.7 & $220.0 \pm 6.2$ \\
\hline $\mathrm{C}$ & 26.02 .04 & 26.8 & $20.0-10.1$ & 4.4 & 0.7 & 13.8 & - & 161.9 & 6.1 & $308.5 \pm 10.9$ \\
\hline $\mathrm{D}$ & 16.03 .04 & 24.8 & $20.0-5.0$ & 2.5 & 0.8 & 16.4 & - & 209.8 & 6.3 & $411.6 \pm 9.8$ \\
\hline E & 06.02 .07 & 27.5 & $13.6-1.6$ & 16.9 & - & - & 0.6 & 170.4 & 8.6 & $161.5 \pm 7.8$ \\
\hline $\mathrm{F}$ & 11.05 .06 & 16.0 & $6.6-6.4$ & 3.6 & - & - & - & 237.3 & 5.3 & $107.8 \pm 4.4$ \\
\hline
\end{tabular}




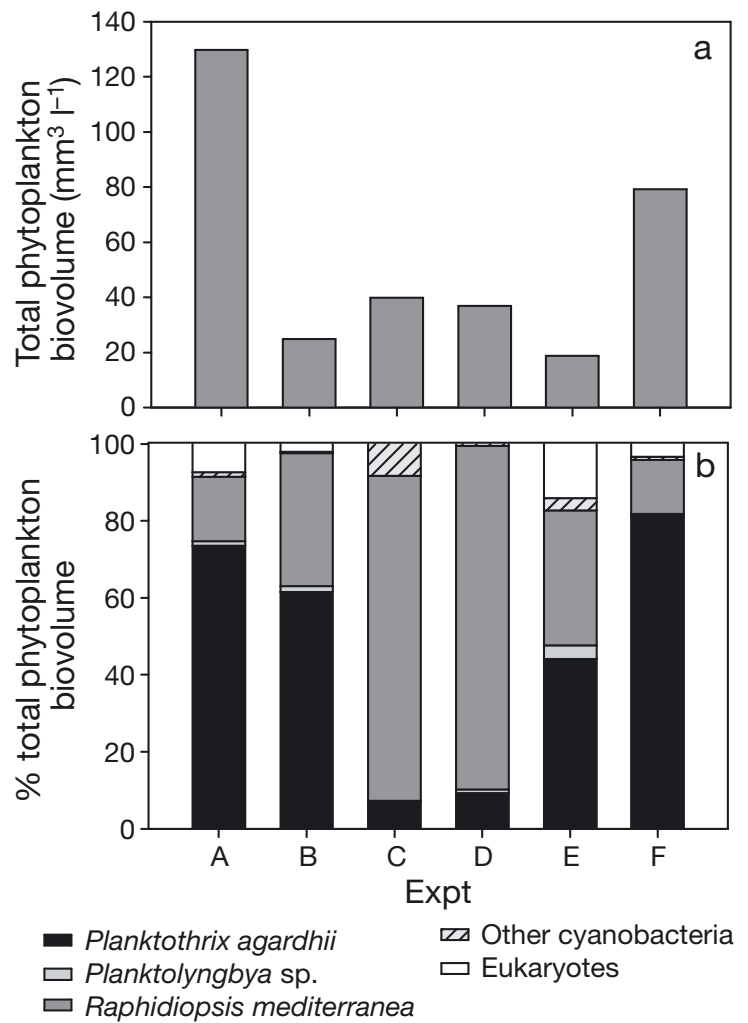

Fig. 2. Phytoplankton from Lago Rodó identified in each experiment (A to F). (a) Total phytoplankton biovolume. (b) Relative contribution of main taxa to total phytoplankton biovolume

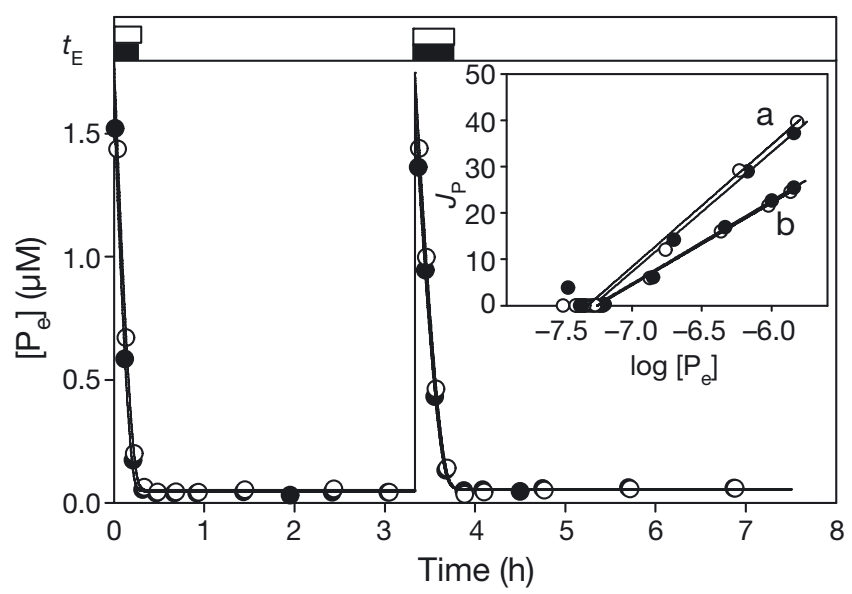

Fig. 3. Expt A. Time course of $\left[{ }^{32} \mathrm{P}\right]$ phosphate removal in phytoplankton subsamples from Lago Rodó (@: $\mathrm{S}_{1}$; O: $\mathrm{S}_{2}$ ) during 2 consecutive phosphate pulses. Top horizontal bars represent the exposure time $\left(t_{\mathrm{E}}\right)$ to external phosphate $\left(\left[\mathrm{P}_{\mathrm{e}}\right]\right)$ during each pulse (black bars: $\mathrm{S}_{1}$ i white bars: $\mathrm{S}_{2}$ ). Curves represent the best fit linear equation applied to time-courses of each subsample. Kinetic parameters are shown in Table 2. Inset: Thellier plot of the concentration dependence of incorporation rates $\left(J_{\mathrm{P}}\right)$ obtained from the time course of phosphate removal in the (a) first and (b) second pulses. $J_{\mathrm{P}}$ is given in $\mu \mathrm{mol} \mathrm{P}_{\mathrm{i}} \mathrm{mg}^{-1} \mathrm{chl} a \mathrm{~h}^{-1}$; $\log \left[\mathrm{P}_{\mathrm{e}}\right]$ is expressed relative to $1 \mathrm{M}$ cally identical uptake properties between subsamples $\mathrm{S}_{1}$ and $\mathrm{S}_{2}$ (Expt A) (Fig. 3, Table 2). Phytoplankton dominated by Planktothrix agardhii achieved nanomolar threshold values $\left(\left[\mathrm{P}_{\mathrm{e}}\right]_{\mathrm{A}}: 50\right.$ and $55 \mathrm{nM}$ for the first and second pulse, respectively). The maximum uptake rate $\left(L_{\mathrm{P}}\right)$ was lower after the second pulse, indicating the beginning of uptake kinetic alterations (Fig. 3 inset) (mean $L_{\mathrm{p}}=45$ and $31 \mathrm{nM}$ $\mathrm{min}^{-1}$ for the first and second pulse, respectively; GLM-ANCOVA, $F=26.4, \mathrm{p}<0.001$ ).

In Expt $B$, the imprinting pulse sequence applied to $\mathrm{S}_{1}$ (10 additions of $1 \mu \mathrm{M}$ phosphate) provoked an extension of $t_{\mathrm{E}}$ relative to $\mathrm{S}_{2}$, which had received a single phosphate pulse of $10 \mu \mathrm{M}\left(t_{\mathrm{E}}=91\right.$ and $43 \mathrm{~min}$ for $\mathrm{S}_{1}$ and $\mathrm{S}_{2}$, respectively) (Fig. $4 \mathrm{a}$ ). As a result, the uptake rate in $\mathrm{S}_{1}$ decreased, as evidenced by a $>2$ fold $L_{\mathrm{P}}$ reduction (Table 2). The initial differences between $S_{1}$ and $S_{2}$ were amplified after applying the test pulses. Phytoplankton of $\mathrm{S}_{1}$ showed a progressive, significant alteration of uptake properties (Fig. 4). The phytoplankton that experienced a longer $t_{\mathrm{E}}$ $\left(\mathrm{S}_{1}\right)$ decreased $L_{\mathrm{P}} 4$-fold after the first test pulse. The

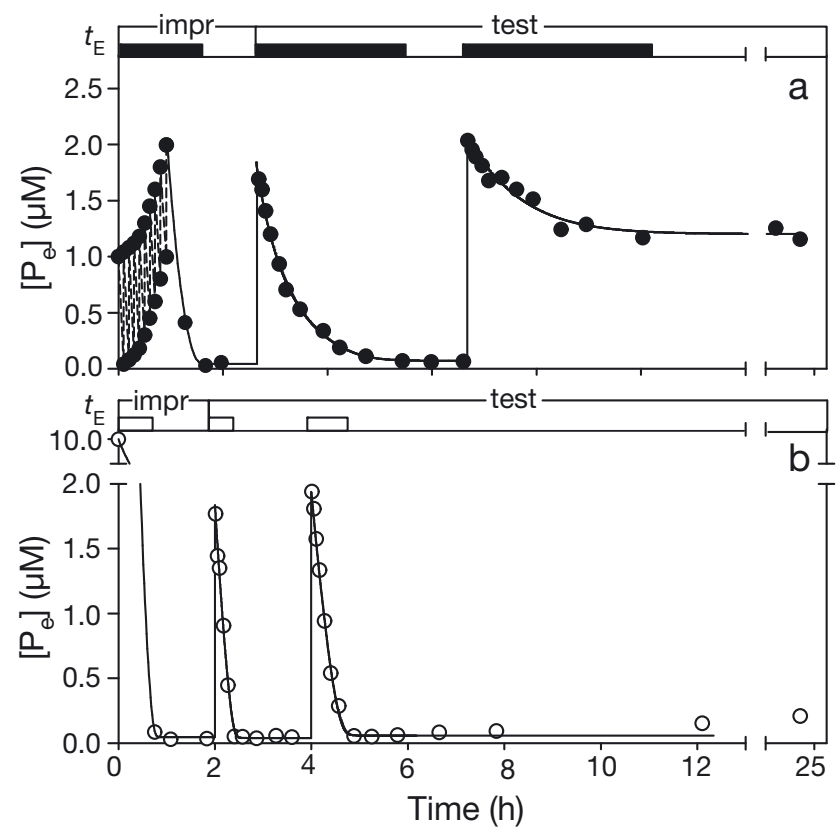

Fig. 4. Expt B. Time course of $\left[{ }^{32} \mathrm{P}\right]$ phosphate removal in 2 identical phytoplankton subsamples $\left(\mathbf{O}: \mathrm{S}_{1} ; \mathrm{O}: \mathrm{S}_{2}\right)$ of Lago Rodó. (a) $\mathrm{S}_{1}$ was exposed to 10 imprinting pulses (impr) of $1 \mu \mathrm{M}$ and (b) $\mathrm{S}_{2}$ to 1 pulse of $10 \mu \mathrm{M}\left[{ }^{32} \mathrm{P}\right]$ phosphate. Two test pulses of $2 \mu \mathrm{M}$ phosphate (test) were applied to each subsample immediately after the attainment of the corresponding threshold values. Curves represent the best fit obtained for each subsample with linear and nonlinear equations (Eqs. $1 \& 2$, respectively). Kinetic parameters are shown in Table 2. Top horizontal bars represent the exposure time $\left(t_{\mathrm{E}}\right)$ to external phosphate $\left(\left[\mathrm{P}_{\mathrm{e}}\right]\right)$ during each pulse 
Table 2. Kinetic parameters of phosphate removal by phytoplankton from Lago Rodó. Expt: experiment, Sbs: subsample, $\left.{ }^{32} \mathrm{P}\right]$ : initial phosphate concentration labelled with the radioactive ${ }^{32} \mathrm{P}$ isotope. Kinetic parameters of the linear and nonlinear curve fitting of flow-force relationship. $L_{\mathrm{P}}$ and $L$ : conductivity coefficients; $\left[\mathrm{P}_{\mathrm{e}}\right]_{\mathrm{A}}$ : threshold value $\pm \mathrm{CI}_{95} \%$ of phosphate uptake; $t_{\mathrm{E}}$ : exposure time to external phosphate concentrations; $r^{2}$ : determination coefficient. Values of $m$ for Eq. (2) are in brackets in column $L$. ${ }^{*}$ Significant differences between subsamples $\mathrm{S}_{1}$ and $\mathrm{S}_{2}$ within the same pulse treatment according to $\mathrm{CI}_{95 \%}{ }^{+}{ }^{+} \mathrm{Signifi}-$ cant differences between pulses within the same subsample according to $\mathrm{CI}_{95 \%}$. ${ }^{\mathrm{x}} L_{\mathrm{p}}$ : significant differences between subsamples $S_{1}$ and $S_{2}$ within the same pulse treatment, ${ }^{\mathrm{xx}} L_{\mathrm{p}}$ : significant differences between pulses within the same subsample (GLMANCOVA, $\mathrm{p}<0.01)$

\begin{tabular}{|c|c|c|c|c|c|c|c|c|}
\hline Expt & Pulse treatment & Sbs & $\begin{array}{c}{\left[{ }^{32} \mathrm{P}\right] \text { pulse }} \\
(\mu \mathrm{M})\end{array}$ & $\begin{array}{c}L_{\mathrm{P}} \\
\left(\mathrm{nM} \mathrm{min}^{-1}\right)\end{array}$ & $\begin{array}{c}L \\
\left(\mathrm{nM} \mathrm{min}^{-1}\right)\end{array}$ & $\begin{array}{l}{\left[\mathrm{P}_{\mathrm{e}}\right]_{\mathrm{A}}} \\
(\mathrm{nM})\end{array}$ & $\begin{array}{c}t_{\mathrm{E}} \\
(\mathrm{min})\end{array}$ & $\mathrm{r}^{2}$ \\
\hline \multirow[t]{4}{*}{ A } & \multirow[t]{2}{*}{ First } & $\mathrm{S}_{1}$ & 1.8 & $45.9^{\mathrm{xx}}$ & - & $48 \pm 33$ & 15 & 0.999 \\
\hline & & $\mathrm{S}_{2}$ & 1.8 & $45.0^{\mathrm{xx}}$ & - & $52 \pm 19$ & 17 & 1.000 \\
\hline & \multirow[t]{2}{*}{ Second } & $\mathrm{S}_{1}$ & 1.8 & $30.8^{\mathrm{xx}}$ & - & $56 \pm 17$ & 24 & 1.000 \\
\hline & & $\mathrm{S}_{2}$ & 1.8 & $31.1^{\mathrm{xx}}$ & - & $54 \pm 24$ & 24 & 1.000 \\
\hline \multirow[t]{6}{*}{ B } & \multirow[t]{2}{*}{ Imprinting } & $\mathrm{S}_{1}$ & 1.0 (10 times) & $17.3^{\mathrm{x}}$ & $0.05(5)$ & $41 \pm 26^{+}$ & 91 & 1.000 \\
\hline & & $\mathrm{S}_{2}$ & 10.0 (once) & $37.0^{\mathrm{x}}$ & $0.05(5)$ & $46 \pm 27$ & 43 & 1.000 \\
\hline & \multirow[t]{2}{*}{ First test } & $\mathrm{S}_{1}$ & 2.0 & $4.0^{\mathrm{x}}$ & $0.10(5)$ & $69 \pm 64^{+}$ & 142 & 0.998 \\
\hline & & $\mathrm{S}_{2}$ & 2.0 & $26.0^{\mathrm{x}}$ & - & $40 \pm 79$ & 27 & 0.997 \\
\hline & \multirow[t]{2}{*}{ Second test } & $\mathrm{S}_{1}$ & 2.0 & $23.0^{\mathrm{x}}$ & $0.10(5)$ & $1201 \pm 121^{*+}$ & 152 & 0.962 \\
\hline & & $\mathrm{S}_{2}$ & 2.0 & $19.0^{\mathrm{x}}$ & - & $62 \pm 83^{*}$ & 44 & 0.997 \\
\hline \multirow[t]{4}{*}{$\mathrm{C}$} & \multirow[t]{2}{*}{ Imprinting } & $\mathrm{S}_{1}$ & 1.0 (10 times) & $1.9^{\mathrm{x}}$ & $0.05(3)$ & $63 \pm 46^{+}$ & 352 & 0.998 \\
\hline & & $\mathrm{S}_{2}$ & 10.0 (once) & $3.9^{\mathrm{x}}$ & $2.00(5)$ & $35 \pm 43$ & 60 & 1.000 \\
\hline & \multirow[t]{2}{*}{ First test } & $\mathrm{S}_{1}$ & 2.0 & $0.7^{\mathrm{x}}$ & $1.00(3)$ & $269 \pm 127^{+}$ & 1644 & 0.980 \\
\hline & & $\mathrm{S}_{2}$ & 2.0 & $1.3^{\mathrm{x}}$ & $0.25(5)$ & $91 \pm 73$ & 338 & 0.997 \\
\hline \multirow[t]{4}{*}{$\mathrm{D}$} & \multirow[t]{2}{*}{ Imprinting } & $\mathrm{S}_{1}$ & 1.0 (10 times) & $1.0^{\mathrm{x}}$ & $0.10(3)$ & $62 \pm 54^{+}$ & 435 & 0.998 \\
\hline & & $\mathrm{S}_{2}$ & 10.0 (once) & $3.3^{\mathrm{x}}$ & $2.25(5)$ & $51 \pm 30$ & 74 & 1.000 \\
\hline & \multirow[t]{2}{*}{ First test } & $\mathrm{S}_{1}$ & 2.0 & $2.1^{\mathrm{x}}$ & $9.00(3)$ & $501 \pm 90^{*+}$ & 950 & 0.991 \\
\hline & & $\mathrm{S}_{2}$ & 2.0 & $0.7^{\mathrm{x}}$ & $0.20(5)$ & $86 \pm 99^{*}$ & 543 & 0.993 \\
\hline \multirow[t]{8}{*}{$\mathrm{E}$} & \multirow[t]{2}{*}{ First imprinting } & $\mathrm{S}_{1}$ & 1.0 & $25.7^{x}$ & - & $25 \pm 33^{+}$ & 15 & 0.998 \\
\hline & & $\mathrm{S}_{2}$ & 3.0 & $19.1^{\mathrm{x}}$ & - & $27 \pm 98^{+}$ & 40 & 0.998 \\
\hline & \multirow[t]{2}{*}{ Second imprinting } & $\mathrm{S}_{1}$ & 3.0 & $18.3^{x}$ & $0.50(3)$ & $39 \pm 22^{+}$ & 39 & 1.000 \\
\hline & & $\mathrm{S}_{2}$ & 1.0 & $15.8^{x}$ & $0.50(3)$ & $44 \pm 14^{+}$ & 29 & 1.000 \\
\hline & \multirow[t]{2}{*}{ First test } & $\mathrm{S}_{1}$ & 2.0 & $12.2^{\mathrm{x}}$ & $0.60(3)$ & $70 \pm 121^{+}$ & 62 & 0.994 \\
\hline & & $\mathrm{S}_{2}$ & 2.0 & $9.3^{\mathrm{x}}$ & $0.50(3)$ & $90 \pm 40^{+}$ & 91 & 0.999 \\
\hline & \multirow[t]{2}{*}{ Second test } & $\mathrm{S}_{1}$ & 2.0 & $5.7^{\mathrm{x}}$ & $1.20(5)$ & $343 \pm 34^{*+}$ & 347 & 0.999 \\
\hline & & $\mathrm{S}_{2}$ & 2.0 & $5.2^{\mathrm{x}}$ & $1.50(5)$ & $493 \pm 34^{*+}$ & 505 & 0.998 \\
\hline \multirow[t]{6}{*}{$\mathrm{F}$} & \multirow[t]{2}{*}{ First imprinting } & $\mathrm{S}_{1}$ & 0.5 & $1.8^{\mathrm{x}}$ & $0.10(3)$ & $11 \pm 20$ & 75 & 0.997 \\
\hline & & $\mathrm{S}_{2}$ & 1.0 & $0.9^{\mathrm{x}}$ & $0.01(3)$ & $20 \pm 18^{+}$ & 223 & 0.999 \\
\hline & \multirow[t]{2}{*}{ Second imprinting } & $\mathrm{S}_{1}$ & 1.0 & $0.5^{\mathrm{x}}$ & $0.10(5)$ & $76 \pm 47$ & - & 0.993 \\
\hline & & $\mathrm{S}_{2}$ & 0.5 & $0.1^{\mathrm{x}}$ & $0.10(5)$ & $57 \pm 43^{+}$ & - & 1.000 \\
\hline & \multirow[t]{2}{*}{ Test } & $\mathrm{S}_{1}$ & 0.2 & $5.8^{\mathrm{x}}$ & - & $89 \pm 4^{*}$ & 129 & 0.999 \\
\hline & & $\mathrm{S}_{2}$ & 0.2 & $3.2^{\mathrm{x}}$ & - & $186 \pm 32^{*+}$ & 159 & 0.822 \\
\hline
\end{tabular}

effect increased after the second test addition, when uptake ceased at a threshold value 20-fold higher than the parallel subsample $\mathrm{S}_{2}$ (Table 2). Consequently, organisms from $\mathrm{S}_{1}$ incorporated less phosphate than those of $S_{2}$, as indicated by the threshold values $\left(\left[\mathrm{P}_{\mathrm{e}}\right]_{\mathrm{A}}=1201 \pm 121 \mathrm{nM}\right.$ and $62 \pm 83 \mathrm{nM}$ phosphate, $\pm 1 \mathrm{CI}_{95 \%}$, for $\mathrm{S}_{1}$ and $\mathrm{S}_{2}$, respectively), which remained constantly higher for $>14 \mathrm{~h}$ (Fig. 4). Phytoplankton was again dominated by Planktothrix agardhii (61\% of biovolume) (Fig. 2).

The effect of several hours of $t_{\mathrm{E}}$ was tested with a less uptake-active community than previous experiments. In this case, $t_{\mathrm{E}}$ was 352 to $435 \mathrm{~min}\left(\mathrm{~S}_{1}\right.$ Expts $\mathrm{C}$ and $\mathrm{D}$, respectively) (Table 2). The test pulses revealed significant differences in uptake behaviour between subsamples the next day (Fig. 5). $\mathrm{S}_{1}$, which experienced a longer $t_{\mathrm{E}}$ the day before, ceased uptake at a threshold 10-fold higher than the parallel subsample $\mathrm{S}_{2}$ (Fig. 5b, Table 2). This higher threshold value was stable for several hours, as confirmed on the third day.

The adaptive response of cyanobacteria, indicated by $\left[\mathrm{P}_{\mathrm{e}}\right]_{\mathrm{A}}$ increase and $L_{\mathrm{P}}$ decrease, had consequences for growth (Expts $\mathrm{C}, \mathrm{D}$ and $\mathrm{E}_{\text {; }}$ Table 3). The higher threshold levels determined in $\mathrm{S}_{1}$ (Expts $\mathrm{C}$ and D) and $S_{2}$ (Expt E) were followed by a significant higher 


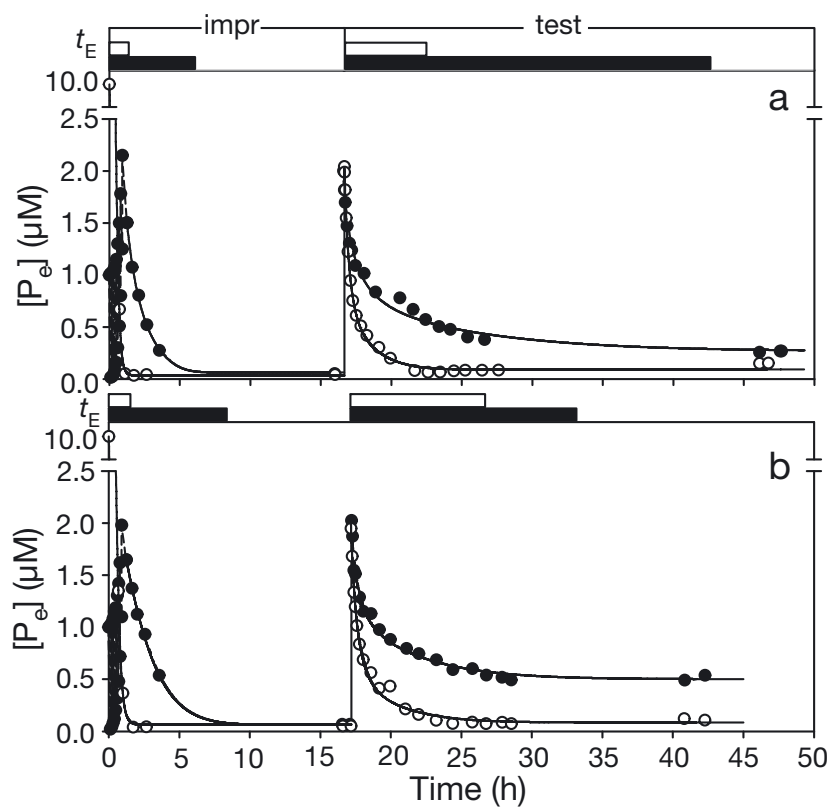

Fig. 5. Expts $\mathrm{C}$ and D. Time course of $\left[{ }^{32} \mathrm{P}\right]$ phosphate removal in 2 identical phytoplankton subsamples $\left(\mathrm{S}_{1}\right.$ O: $\left.\mathrm{S}_{2}\right)$ of Lago Rodó in (a) Expt C and (b) Expt D. $\mathrm{S}_{1}$ was exposed to 10 imprinting pulses of $1 \mu \mathrm{M}$, and $\mathrm{S}_{2}$ was exposed to 1 pulse of $10 \mu \mathrm{M}\left[{ }^{32} \mathrm{P}\right]$ phosphate (impr). Initial and final concentrations of external phosphate $\left(\left[\mathrm{P}_{\mathrm{e}}\right]\right)$ are shown after each pulse of $1 \mu \mathrm{M}$. At $17 \mathrm{~h}$ after initiation, 1 pulse of $2 \mu \mathrm{M}$ phosphate was applied to $\mathrm{S}_{1}$ and $\mathrm{S}_{2}$ (test). Curves represent the best fit obtained for each subsample with the nonlinear Eq. (2) (Table 2). Top horizontal bars represent the exposure time $\left(t_{\mathrm{E}}\right)$ to external phosphate during each pulse (black bars: $\mathrm{S}_{1}$; white bars: $\mathrm{S}_{2}$ )

growth rate (Expt $\mathrm{C}: \mu=0.48 \pm 0.03$ and $0.11 \pm$ $0.05 \mathrm{~d}^{-1}$, Expt D: $\mu=0.73 \pm 0.04$ and $0.56 \pm 0.02 \mathrm{~d}^{-1}$ and Expt E: $\mu=0.09 \pm 0.01$ and $0.12 \pm 0.01 \mathrm{~d}^{-1}$ for $S_{1}$ and $\mathrm{S}_{2}$, respectively; Table 3 ) and chl a production in Expts C and D (Table 3). Conversely, differences in growth rate were not found when the same $t_{\mathrm{E}}$

Table 3. Comparison of growth rates $(\mu)$ and chlorophyll a production (chl a) between subsamples (Sbs) $S_{1}$ and $S_{2}$ of Expts C, D and E (means $\pm \mathrm{SD}$ ). Chl $a$ was measured at the end of incubation (49 h). Differences between subsamples were all significant (Kruskal-Wallis test, p < 0.05) except for chl a values of Expt E

\begin{tabular}{|c|c|c|c|c|}
\hline Expt & $\begin{array}{c}\text { Date } \\
\text { (d.mo.yr) }\end{array}$ & Sbs & $\underset{\left(d^{-1}\right)}{\mu}$ & $\begin{array}{c}\text { Chl a } \\
\left(\mu \mathrm{g} \mathrm{l}^{-1}\right)\end{array}$ \\
\hline \multirow[t]{2}{*}{$\mathrm{C}$} & 26.02 .04 & $\mathrm{~S}_{1}$ & $0.48 \pm 0.03$ & $524.5 \pm 35.5$ \\
\hline & & $\mathrm{S}_{2}$ & $0.11 \pm 0.05$ & $391.3 \pm 11.8$ \\
\hline \multirow[t]{2}{*}{ D } & 16.03 .04 & $\mathrm{~S}_{1}$ & $0.73 \pm 0.04$ & $475.2 \pm 15.6$ \\
\hline & & $\mathrm{S}_{2}$ & $0.56 \pm 0.02$ & $375.7 \pm 31.3$ \\
\hline \multirow[t]{2}{*}{$\mathrm{E}$} & 06.02 .07 & $\mathrm{~S}_{1}$ & $0.09 \pm 0.01$ & $220.0 \pm 67.4$ \\
\hline & & $\mathrm{S}_{2}$ & $0.12 \pm 0.01$ & $250.1 \pm 63.0$ \\
\hline
\end{tabular}

between $\mathrm{S}_{1}$ and $\mathrm{S}_{2}$ resulted in similar uptake kinetics (data not shown). In Expts C and D the phytoplankton community was dominated by Raphidiopsis mediterranea (84 and $89 \%$ of biovolume, respectively) and co-dominated with Planktothrix agardhii in Expt E (35 and $44 \%$ of biovolume, respectively) (Fig. 2).

\section{Cumulative effect of $t_{\mathrm{E}}$ on the adaptive response}

The accumulated $t_{\mathrm{E}}$ during a sequence of phosphate pulses resulted in a progressive adaptive response (Expts E and F). The same imprinting phosphate concentrations applied in reverse order $\left(S_{1}\right.$ : smaller then greater and $\mathrm{S}_{2}$ : greater then smaller) led to a differentiation between subsamples (Fig. 6). $\mathrm{S}_{2}$, which first received the greater pulse, responded with a gradual reduction of phosphate uptake activity. In Expt E (Fig. 6a), the resulting $t_{\mathrm{E}}$ was 2 -fold

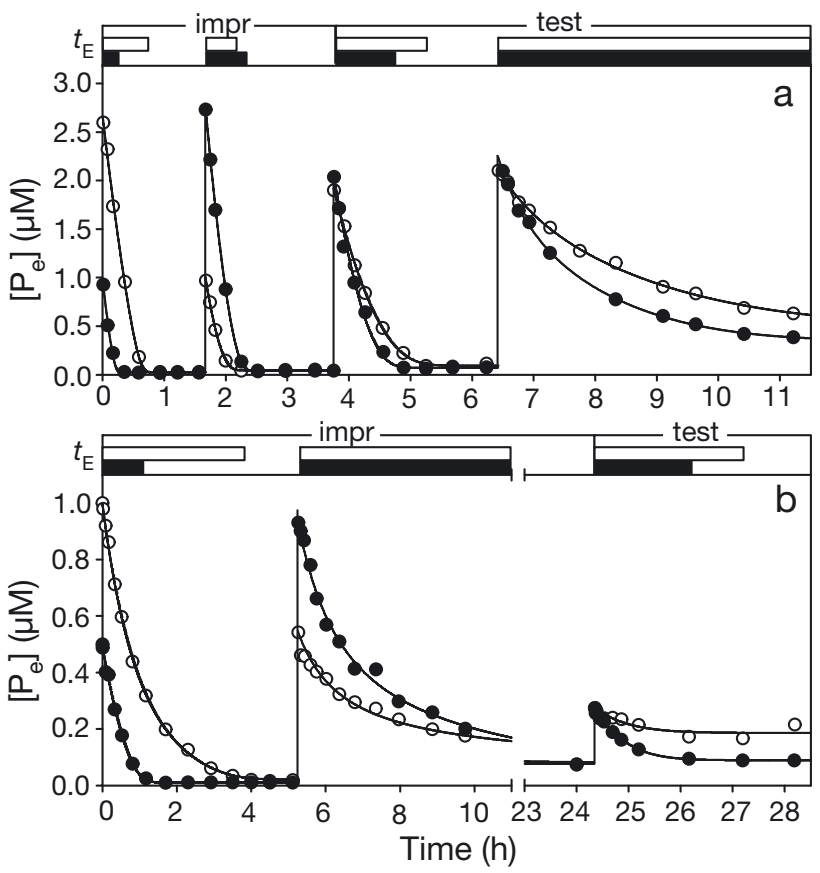

Fig. 6. Expts E and F. Time course of $\left[{ }^{32} \mathrm{P}\right]$ phosphate removal in 2 identical phytoplankton subsamples $\left(\mathrm{S}_{1} ; \mathrm{O}: \mathrm{S}_{2}\right)$ from Lago Rodó. (a) Expt E: $\mathrm{S}_{1}$ was exposed to 1 pulse of $1 \mu \mathrm{M}$ followed by the addition of $3 \mu \mathrm{M}_{i} \mathrm{~S}_{2}$ was exposed to 1 pulse of $3 \mu \mathrm{M}$ followed by the application of $1 \mu \mathrm{M}\left[{ }^{32} \mathrm{P}\right]$ phosphate (impr). Then, both subsamples were subjected to 2 test phosphate pulses of $2 \mu \mathrm{M}$ (test). (b) Expt F: $\mathrm{S}_{1}$ was exposed to 1 pulse of $0.5 \mu \mathrm{M}$ followed by $1 \mu \mathrm{M}$ addition, and $\mathrm{S}_{2}$ had 1 pulse of $1 \mu \mathrm{M}$ applied followed by $0.5 \mu \mathrm{M}$ phosphate (impr). At $24 \mathrm{~h}$ after the first phosphate addition, both subsamples were subjected to 1 phosphate pulse of $0.2 \mu \mathrm{M}$ (test). Curves represent the best fit using linear and nonlinear equations

(Table 2). See Fig. 5 for further details 
higher in the greater-then-smaller imprinting pattern $\left(\mathrm{S}_{2}\right)$ than in the smaller-then-greater one $\left(\mathrm{S}_{1}\right)\left(t_{\mathrm{E}}: 15\right.$ and $29 \mathrm{~min}$ in $\mathrm{S}_{1}$ and $\mathrm{S}_{2}$, respectively, after $1 \mu \mathrm{M}$ phosphate). Also, the $L_{\mathrm{P}}$ values obtained from the imprinting pulses of each subsample were different (Table 2), evidenced in the cumulative $t_{\mathrm{E}}\left(\sum t_{\mathrm{E}}: 54\right.$ and 69 min for the $S_{1}$ and $S_{2}$ imprinting pulses, respectively). This difference was amplified after the test pulses, and as a consequence, $\mathrm{S}_{2}$ showed the higher threshold value (Fig. 6a). The low phosphate uptake activity shown by phytoplankton in Expt F resulted in an extended $t_{\mathrm{E}}$ (Fig. 6b). The high $\left[\mathrm{P}_{\mathrm{e}}\right]_{\mathrm{A}}$ values were stable for $>24 \mathrm{~h}$ after the imprinting procedure was initiated. Phytoplankton of both subsamples again showed significant differences in threshold values and $L_{\mathrm{P}}$. The community was again dominated by Planktothrix agardhii.

The $t_{\mathrm{R}}$ is obtained when the effect of $t_{\mathrm{E}}$ on threshold values and maximum uptake rates from all of the experiments is analyzed (Fig. 7). The increase of threshold values positively correlated with $t_{\mathrm{E}}$ (Fig. 7a) ( $\left.\mathrm{r}^{2}=0.89, \mathrm{n}=18, F=135, \mathrm{p}<0.0001\right)$. In gen-
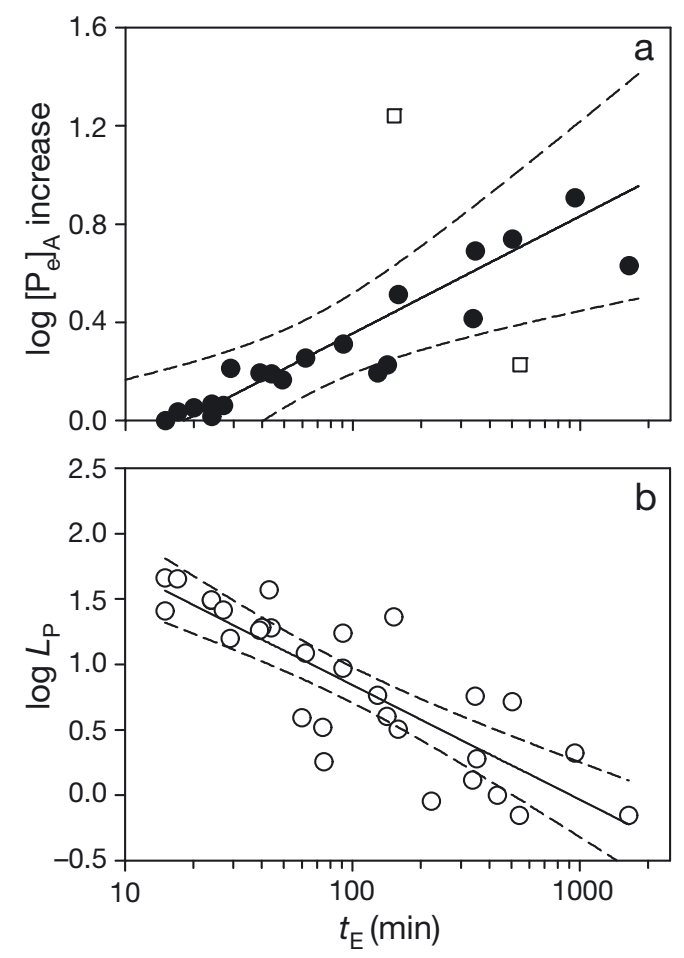

Fig. 7. Adaptive response of phytoplankton, assessed as (a) the increase of threshold value for uptake of external phosphate $\left(\left[\mathrm{P}_{\mathrm{e}}\right]_{\mathrm{A}}\right)$ as a function of the exposure time $\left(t_{\mathrm{E}}\right)$ during the same phosphate addition. The best fit was obtained with the equation $y=-0.6002+0.2074 \ln (x) ; \mathrm{r}^{2}=0.89, F=135, \mathrm{n}=$ 18, p $<0.0001 . \quad \square$ : outliers. (b) Decrease of $L_{\mathrm{P}}$ as a function of $t_{\mathrm{E}}$. Best fit was obtained with the equation $y=2.5946-$ $0.3805 \ln (x) ; r^{2}=0.70, F=66, \mathrm{n}=30, \mathrm{p}<0.0001$. Dashed lines represent $95 \%$ confidence interval eral, initial $\left[\mathrm{P}_{\mathrm{e}}\right]_{\mathrm{A}}$ values were $42 \pm 16 \mathrm{nM}$, with a minimum value of $11 \mathrm{nM}$ phosphate, before the adaptive response took place. After the adaptive response, $\left[\mathrm{P}_{\mathrm{e}}\right]_{\mathrm{A}}$ values increased up to 3 orders of magnitude and remained high for $>15 \mathrm{~h}$. The general tendency shown in Fig. 7 a illustrates that the adaptive response found in cyanobacteria-dominated phytoplankton begins after ca. 25 min of exposure to phosphate since all threshold values are higher after that time. The fitted equation intercepts the $t_{\mathrm{E}}$ axis at $18 \mathrm{~min}$ (no significant effect), and an almost 2-fold increase of $\left[\mathrm{P}_{\mathrm{e}}\right]_{\mathrm{A}}$ was determined at a $t_{\mathrm{E}}$ of $29 \mathrm{~min}$. The maximum $\left[\mathrm{P}_{\mathrm{e}}\right]_{\mathrm{A}}$ was 16.4 -fold higher after a $t_{\mathrm{E}}$ of 150 min. Fig. 7b shows the significant decrease of $L_{\mathrm{P}}$ with $t_{\mathrm{E}}\left(\mathrm{r}^{2}=0.70, \mathrm{n}=30, F=66, \mathrm{p}<0.0001\right)$. The maximum $L_{\mathrm{P}}$ values were obtained within 15 to $17 \mathrm{~min}$ of $t_{\mathrm{E}}$. All values of uptake rate were lower after this $t_{\mathrm{E}}$ range.

\section{DISCUSSION}

\section{Reaction time of bloom-forming cyanobacteria to available phosphate}

Our results revealed that bloom-forming cyanobacteria have a rapid reaction to available phosphate, which begins within 15 to 25 min of nutrient exposure. When the $t_{\mathrm{E}}$ to external phosphate surpasses $t_{\mathrm{R}}$, cyanobacteria progressively adjust their uptake properties (e.g. Fig. 3). The $L_{\mathrm{P}}$ and $\left[\mathrm{P}_{\mathrm{e}}\right]_{\mathrm{A}}$ are inverse and directly proportional to $t_{\mathrm{E}}$, respectively. This proportional effect of $t_{\mathrm{E}}$ on the adaptive response allowed the attainment of new uptake properties that were stable for several hours, which in turn affected growth rate. It is remarkable that the higher growth rate found with longer $t_{\mathrm{E}}$ was achieved when relatively less phosphate was taken up in comparison with the shorter $t_{\mathrm{E}}$ treatment, which confirms the energetic benefit of the adaptive response. Therefore, rapid phosphate fluctuations on the timescale of minutes have direct consequences for further growth.

The sequence of small pulses applied within a short time interval determined that the cyanobacteria-dominated community was not able to achieve the threshold value after each pulse, so the organisms experienced a persistent elevated external phosphate concentration over time. This relatively long exposure to phosphate may occur in a lake when phosphate dilutes in the water column (Aubriot et al. 2000), for example during nutrient release from sediments or inflow events after rainfall (Glibert et al. 
2008). In contrast, very short nutrient pulse events may occur during local small inputs in a lake (e.g. excretion by zooplankton), in which the uptake properties may remain relatively unchanged if $t_{\mathrm{E}} \leq t_{\mathrm{R}}$ (e.g. Fig. 3). Therefore, our results offer a new perspective on what can be considered as a significant input of phosphate into the water column, enough to induce a physiological and growth response of cyanobacteria. The $t_{\mathrm{R}}$ of cyanobacterial populations and its proportional response are crucial variables for future models of flexible nutrient uptake that attempt to predict bloom formation.

The adaptive response to $t_{\mathrm{E}}$ may be driven by the biomass-dominant populations; however, the $t_{\mathrm{R}}$ of other coexisting planktonic members may be within

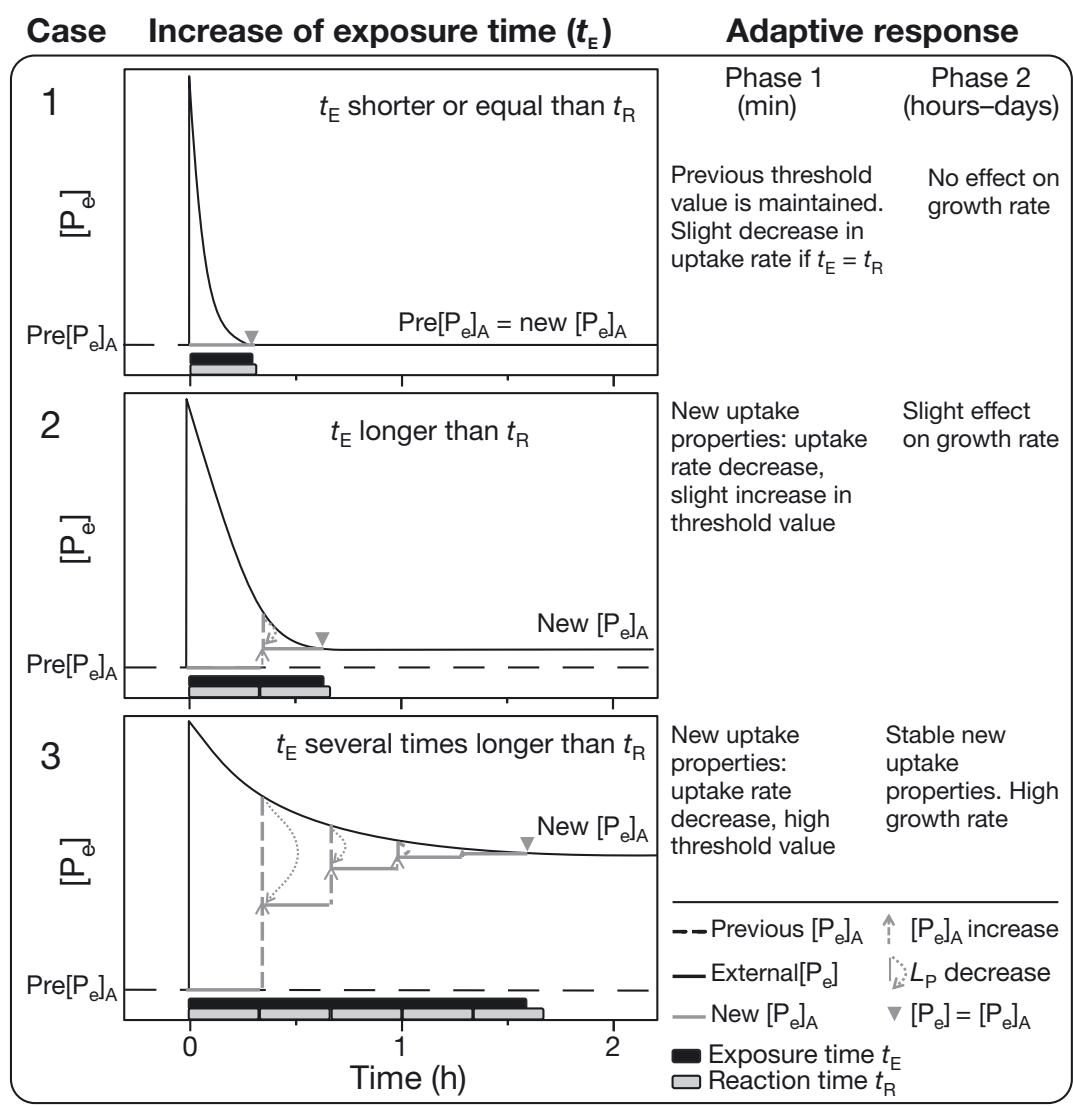

Fig. 8. Conceptual diagram of the influence of exposure time $\left(t_{\mathrm{E}}\right)$ and reaction time $\left(t_{\mathrm{R}}\right)$ on adaptive phosphate uptake. Case 1: $t_{\mathrm{E}} \leq t_{\mathrm{R}}$, uptake of a low concentration phosphate pulse or by highly uptake-active cyanobacterial populations. Case 2: $t_{\mathrm{E}}>t_{\mathrm{R}}$, uptake of higher concentration phosphate pulse or by less uptake-active cyanobacteria. New uptake properties are observed during Phase 1 and slight effect on growth rate can be determined (Phase 2). Case 3: long $t_{\mathrm{E}}\left(>>t_{\mathrm{R}}\right)$ provoked by a previous phosphate pulse exposure (i.e. sequence of 10 pulses) or during a persistent pulse addition. New uptake properties are long-term stable (Phases 1 and 2) with resulting growth optimisation (Phase 2). $\left[\mathrm{P}_{\mathrm{e}}\right]$ : external phosphate concentration; $\left[\mathrm{P}_{\mathrm{e}}\right]_{\mathrm{A}}$ : threshold concentration at which phosphate uptake ceases the same range as that of cyanobacteria. Phytoplankton composition and biomass in our study was typical of hypereutrophic ecosystems, dominated by filamentous cyanobacteria ( $>83 \%$ of biovolume), although bacterioplankton and eukaryote phytoplankton were present. Bacterioplankton biomass in Lago Rodó is low in comparison with other hypertrophic lakes (3.6\% of total phytoplankton and bacterioplankton biovolume) (Sommaruga 1995, Sommaruga \& Robarts 1997). The adaptive response was found either with Planktothrix agardhii dominance (Expts A, B and F), Raphidiopsis mediterranea dominance (Expts $\mathrm{C}$ and D) or co-dominance (Expt E). For example, $L_{\mathrm{P}}$ was 1 order of magnitude higher in Expt B than in Expt $F$, both under the dominance of $P$. agardhii. Phytoplankton of Lago Rodó was previously found to exhibit a common threshold value that precludes direct competition (Aubriot et al. 2011). The increased threshold value, which is indeed available phosphate, persists for a long-term period (days) because no additional uptake takes place. Our present and previous results (Aubriot et al. 2011) suggest that this adaptive behaviour is paradoxical in the context of resource competition theory since potential competitors would have more phosphate available in the environment for their growth. We identified a higher growth rate when relatively less phosphate was taken up, which can be explained by a significant increase in the efficiency of energy conversion during the acquired adapted state (Falkner et al. 1989, 1994, Wagner et al. 2000, Plaetzer et al. 2005). Growth response may therefore be more dependent on the ability of cyanobacteria to optimise the uptake of phosphate during the time span of nutrient fluctuation than on the amount of nutrient taken up perse.

\section{Influence of $t_{\mathrm{R}}$ on growth optimisation}

Cyanobacteria may reach higher nutrient exploitation efficiency in 2 consecutive phases. The rapid (minutes) adaptive response is the initial 
physiological response (Phase 1) to the ongoing nutrient fluctuation that affects further growth (Phase 2). In the first phase, the adaptive response will not take place if $t_{\mathrm{E}}$ is shorter than $t_{\mathrm{R} i}$ thus, cyanobacteria maintain the same uptake properties (Fig. 8, Case 1). The adaptive response starts when $t_{\mathrm{E}}$ meets $t_{R}$ with an $L_{\mathrm{P}}$ decrease while the threshold value is maintained relatively constant $\left(t_{\mathrm{E}}<20 \mathrm{~min}\right)$ (Fig. 8, Case 1). If $t_{\mathrm{E}}$ is extended, cyanobacteria increase the threshold value concomitantly with a new adjustment of $L_{\mathrm{P}}\left(t_{\mathrm{E}}>20 \mathrm{~min}\right)$ (Fig. 8, Case 2). This kinetic and energetic adaptation takes place toward the optimum efficiency of energy conversion (Falkner et al. 1989, Wagner et al. 1995, Plaetzer et al. 2005). In the initial phase $\left(t_{\mathrm{E}} \leq t_{\mathrm{R}}\right)$, uptake properties follow the linear flow-force equation. When this stable state is perturbed by longer $t_{\mathrm{E}}$, it results in a transient shift from linear to nonlinear kinetic uptake behaviour. A state of optimum efficiency is achieved when the linear relationship between phosphate flow and the driving force of this process is re-established at a higher threshold value (Fig. 8, Case 3) (Falkner et al. 1989, 1993). This complex regulation of cellular uptake systems can be explained in single cyanobacteria by concurrently operating binding sites of membrane proteins with different phosphate affinity (Wagner et al. 1994, Pitt et al. 2010). The absence of 1 of the high-affinity phosphate-binding proteins $(\operatorname{sphX})$ disables the capacity of a Synechococcus mutant to adapt to phosphate pulses, although it can still incorporate phosphate down to nanomolar levels (Falkner et al. 1998). In the case of a community, the transient nonlinear behaviour may be the result of small specific differences in $t_{\mathrm{R}}$ during adaptation, for example between filamentous cyanobacteria and bacterioplankton. In this short-term process, environmental information is stored in the newly acquired kinetic and energetic properties, which result in a novel adapted state (Wagner et al. 1995, Falkner et al. 2006, Aubriot et al. 2011). We hypothesise, therefore, that this initial response may mark the onset of more stable, long-lasting acclimated states (hours to days).

In a second longer-term phase (hours to days), the biochemical reconstruction of the uptake systems is expected (i.e. a new array of phosphate binding proteins). This nutrient acclimated state may be the case in Expts $C, D$ and $F$, in which the new energetic and kinetic properties were stable for $>24 \mathrm{~h}$ with resulting growth optimisation (Fig. 8, Case 3). The longterm effects observed in these experiments suggest a new functional organisation of membrane proteins via Pho regulon expression (Juntarajumnong et al.
2007, Burut-Archanai et al. 2009, Kimura et al. 2009). Changes in gene expression of phosphate binding proteins in Synechocystis (Pitt et al. 2010) and Trichodesmium (Orchard et al. 2009) as well as membrane protein patterns in Synechococcus (Wagner et al. 1994, Scanlan et al. 1997) occurred on 1 to several days following phosphate enrichment, despite the wide range of growth rates $\left(\sim 0.2 \mathrm{~d}^{-1}\right.$ and up to $2.0 \mathrm{~d}^{-1}$ of Trichodesmium sp. and Synechococcus sp., respectively). Gene expression of alkaline phosphatases drops faster (by $4 \mathrm{~h}$ ) than enzyme activity, which decreases more slowly after phosphate supply (Orchard et al. 2009). Since the reaction of cyanobacteria takes minutes, $t_{\mathrm{R}}$ may be attributed to the regulation of the existing array of uptake systems. We propose that the rapid physiological adaptation allows a 'real-time' response within the timescale of environmental nutrient fluctuation. This adaptive process may occur in connection to the second phase, by which cyanobacteria are able to acclimate to experienced nutrient fluctuations by the reconstruction of uptake systems. It remains to be established if cyanobacteria growing under rapidly fluctuating nutrient conditions (i.e. very active phosphate removal by dense populations in eutrophic freshwaters that results in rapid fluctuation) may differ in $t_{R}$ from those that are dominant in more stable environments (i.e. oligotrophic seas).

The rapid adaptive behaviour may explain the predominance of bloom-forming cyanobacteria in freshwaters under apparently suboptimal conditions. As shown here and in other studies, Planktothrix agardhii is able to endure several months with phosphate concentrations below detection limits (Catherine et al. 2008). The predominance of bloom forming cyanobacteria must be maintained by phosphate fluctuations that are invisible to lake monitoring programs due to their short timescales (Glibert et al. 2008) and low cyanobacterial threshold values. For instance, the minimum threshold value found in our study was $11 \mathrm{nM}$ phosphate, which is below the detection limit of standard methods (>100 nM). In our experiments, the external phosphate concentration was raised to levels sufficient to double the biomass. After such additions, phosphate concentrations decreased to nanomolar levels in $<1 \mathrm{~h}$. Similarly, the dominance of the invasive Cylindrospermopsis raciborskii is achieved by sporadic (periodic) large or small phosphate additions (Posselt et al. 2009), besides its advantageous phosphate uptake properties (Isvánovics et al. 2000). Furthermore, a recent worldwide lake dataset study suggested that C. raciborskii is physiologically more flexible than P. agard- 
hii, which may explain its ongoing expansion (Piccini et al. 2011, Bonilla et al. 2012). We suggest that resilience of cyanobacteria populations in eutrophic freshwaters may be related to their capability to respond rapidly in order to match the timescale of phosphate fluctuations.

We have shown here the $t_{\mathrm{R}}$ of adaptive phosphate uptake by natural cyanobacterial blooms. These organisms are able to adjust the energetic and kinetic properties of phosphate uptake within minutes. This short $t_{\mathrm{R}}$ allows for growth optimisation. Further studies of flexible physiological responses of cyanobacteria to environmental fluctuations may identify early stages of bloom formation. The time required for physiological adaptive responses and the concomitant energetic and kinetic adjustments of phosphate uptake are crucial for the development of realistic models to advance in cyanobacterial bloom predictions.

Acknowledgements. We thank G. Falkner for advising our study. We also thank R. Falkner, L. Acerenza, D. Conde and M. Masdeu for helpful discussions. This study was supported by the financial help of Universidad de la República, CSIC, PEDECIBA-Basic Science Development Program of Uruguay, DINACYT-Uruguay (N 7026), SNI-ANII and ANII projects FCE2007_353 and PR_FCE_2009_1_2330.

\section{LITERATURE CITED}

> Antenucci JP, Ghadouani A, Burford MA, Romero JR (2005) The long-term effect of artificial destratification on phytoplankton species composition in a subtropical reservoir. Freshw Biol 50:1081-1093

> Aubriot L, Wagner F, Falkner G (2000) The phosphate uptake behaviour of phytoplankton communities in eutrophic lakes reflects alterations in the phosphate supply. Eur J Phycol 35:255-262

> Aubriot L, Bonilla S, Falkner G (2011) Adaptive phosphate uptake behaviour of phytoplankton to environmental phosphate fluctuations. FEMS Microbiol Ecol 77:1-16

Bonachela JA, Raghib M, Levin SA (2011) Dynamic model of flexible phytoplankton nutrient uptake. Proc Natl Acad Sci USA 108:20633-20638

Bonilla S, Aubriot L, Soares MCS, González-Piana M and others (2012) What drives the distribution of the bloomforming cyanobacteria Planktothrix agardhii and Cylindrospermopsis raciborskii? FEMS Microbiol Ecol 79: 594-607

Burford MA, O'Donohue MJ (2006) A comparison of phytoplankton community assemblages in artificially and naturally mixed subtropical water reservoirs. Freshw Biol 51:973-982

- Burut-Archanai S, Incharoensakdi A, Eaton-Rye JJ (2009) The extended n-terminal region of $\mathrm{SphS}$ is required for detection of external phosphate levels in Synechocystis sp. PCC 6803. Biochem Biophys Res Commun 378 . 383-388
Button DK (1998) Nutrient uptake by microorganisms according to kinetic parameters from theory as related to cytoarchitecture. Microbiol Mol Biol Rev 62:636-645

> Casey JR, Lomas MW, Michelou VK, Dyhrman ST, Orchard ED, Ammerman JW, Sylvan JB (2009) Phytoplankton taxon-specific orthophosphate (Pi) and ATP utilization in the western subtropical North Atlantic. Aquat Microb Ecol 58:31-44

Catherine A, Quiblier C, Yéprémian C, Got P and others (2008) Collapse of a Planktothrix agardhii perennial bloom and microcystin dynamics in response to reduced phosphate concentrations in a temperate lake. FEMS Microbiol Ecol 65:61-73

Falkner R, Falkner G (2003) Distinct adaptivity during phosphate uptake by the cyanobacterium Anabaena variabilis reflects information processing about preceding phosphate supply. J Trace Microprobe Tech 21:363-375

Falkner G, Falkner R, Schwab A (1989) Bioenergetic characterization of transient state phosphate uptake by the cyanobacterium Anacystis nidulans. Arch Microbiol 152: 353-361

Falkner G, Falkner R, Wagner W (1993) Adaptive phosphate uptake behaviour of the cyanobacterium Anacystis nidulans: analysis by a proportional flow-force relation. C R Acad Sci III 316:784-787

Falkner G, Wagner F, Falkner R (1994) On the relation between phosphate uptake and growth of the cyanobacterium Anacystis nidulans. C R Acad Sci III 317: 535-541

Falkner G, Wagner F, Small JV, Falkner R (1995) Influence of fluctuating phosphate supply on the regulation of phosphate uptake by the blue-green alga Anacystis nidulans. J Phycol 31:745-753

Falkner R, Wagner F, Aiba H, Falkner G (1998) Phosphateuptake behaviour of a mutant of Synechococcus sp. PCC 7942 lacking one protein of the high-affinity phosphateuptake system. Planta 206:461-465

Falkner R, Priewasser M, Falkner G (2006) Information processing by cyanobacteria during adaptation to environmental phosphate fluctuations. Plant Signal Behav 1: 212-220

Glibert PM, Kelly V, Alexander J, Codispoti LA, Boicourt WC, Trice TM, Michael B (2008) In situ nutrient monitoring: a tool for capturing nutrient variability and the antecedent conditions that support algal blooms. Harmful Algae 8:175-181

Gotelli NJ, Colwell RK (2010) Estimating species richness. In: Magurran AE, McGill BJ (eds) Biological diversity: frontiers in measurement and assessment. Oxford University Press, Oxford, p 39-54

Guillard R (1978) Counting slides. In: Sournia A (ed) Phytoplankton manual. UNESCO, Paris, p 182-190

Hillebrand H, Dürselen C, Kirschtel D, Zohary T, Pollingher U (1999) Biovolume calculation for pelagic and benthic microalgae. J Phycol 35:403-424

Is[t]vánovics V, Shafik HM, Présing M, Juhos S (2000) Growth and phosphate uptake kinetics of the cyanobacterium Cylindrospermopsis raciborskii (Cyanophyceae) in throughflow cultures. Freshw Biol 43:257-275

- Juntarajumnong W, Hirani T, Simpson J, Incharoensakdi A, Eaton-Rye J (2007) Phosphate sensing in Synechocystis sp. PCC 6803: SphU and the SphS-SphR two-component regulatory system. Arch Microbiol 188:389-402

Kimura S, Shiraiwa Y, Suzuki I (2009) Function of the N-terminal region of the phosphate-sensing histidine kinase, 
SphS, in Synechocystis sp. PCC 6803. Microbiology 155: 2256-2264

Moutin T, Thingstad TF, van Wambeke F, Marie D, Slawyk G, Raimbault P, Claustre H (2002) Does competition for nanomolar phosphate supply explain the predominance of the cyanobacterium Synechococcus? Limnol Oceanogr 47:1562-1567

Nusch E (1980) Comparisons of different methods for chlorophyll and phaeopigments determination. Arch Hydrobiol Beih Ergeb Limnol 14:14-36

Orchard ED, Webb EA, Dyhrman ST (2009) Molecular analysis of the phosphorus starvation response in Trichodesmium spp. Environ Microbiol 11:2400-2411

Piccini C, Aubriot L, Fabre A, Amaral V and others (2011) Genetic and eco-physiological differences of South American Cylindrospermopsis raciborskii isolates support the hypothesis of multiple ecotypes. Harmful Algae 10:644-653

Pitt FD, Mazard S, Humphreys L, Scanlan DJ (2010) Functional characterization of Synechocystis sp. strain PCC 6803 pst1 and pst2 gene clusters reveals a novel strategy for phosphate uptake in a freshwater cyanobacterium. J Bacteriol 192:3512-3523

Plaetzer K, Thomas SR, Falkner R, Falkner G (2005) The microbial experience of environmental phosphate fluctuations. An essay on the possibility of putting intentions into cell biochemistry. J Theor Biol 235:540-554

> Posselt AJ, Burford MA, Shaw G (2009) Pulses of phosphate promote dominance of the toxic cyanophyte Cylindrospermopsis raciborskii in a subtropical water reservoir. J Phycol 45:540-546

Rigler FH (1956) A tracer study of the phosphorus cycle in lake water. Ecology 37:550-562

Scanlan DJ, Silman NJ, Donald KM, Wilson WH, Carr NG, Joint I, Mann NH (1997) An immunological approach to detect phosphate stress in populations and single cells of photosynthetic picoplankton. Appl Environ Microbiol 63: 2411-2420

Scheffer M, Rinaldi S, Gragnani A, Mur L, van Nes EH (1997) On the dominance of filamentous cyanobacteria in shallow, turbid lakes. Ecology 78:272-282

Schwarz R, Forchhammer K (2005) Acclimation of unicellular cyanobacteria to macronutrient deficiency: emergence of a complex network of cellular responses. Microbiology 151:2503-2514

Sommaruga R (1995) Microbial and classical food webs: a visit to a hypertrophic lake. FEMS Microbiol Ecol 17: 257-270

Editorial responsibility: Patricia Glibert,

Cambridge, Maryland, USA
Sommaruga R, Robarts RD (1997) The significance of autotrophic and heterotrophic picoplankton in hypertrophic ecosystems. FEMS Microbiol Ecol 24:187-200

Stomp M, van Dijk MA, van Overzee HMJ, Wortel MT and others (2008) The timescale of phenotypic plasticity and its impact on competition in fluctuating environments. Am Nat 172:E169-E185, doi: 10.1086/591680

Strickland JDH, Parsons TR (1972) A practical handbook of seawater analysis. Bull Fish Res Board Can 167:1-310

> Suzuki S, Ferjani A, Suzuki I, Murata N (2004) The SphSSphR two component system is the exclusive sensor for the induction of gene expression in response to phosphate limitation in Synechocystis. J Biol Chem 279: 13234-13240

Tambi H, Flaten GAF, Egge JK, Bødtker G, Jacobsen A, Thingstad TF (2009) Relationship between phosphate affinities and cell size and shape in various bacteria and phytoplankton. Aquat Microb Ecol 57:311-320

Tanaka T, Rassoulzadegan F, Thingstad TF (2004) Orthophosphate uptake by heterotrophic bacteria, cyanobacteria, and autotrophic nanoflagellates in Villefranche Bay, northwestern Mediterranean: vertical, seasonal, and short-term variations of the competitive relationship for phosphorus. Limnol Oceanogr 49:1063-1072

Thellier M (1970) An electrokinetic interpretation of the functioning of biological systems and its application to the study of mineral salt absorption. Ann Bot (Lond) 34: 983-1009

Vadstein O, Olsen Y (1989) Chemical composition and phosphate uptake kinetics of limnetic bacterial communities cultured in chemostats under phosphorus limitation. Limnol Oceanogr 34:939-946

> Valderrama JC (1981) The simultaneous analysis of total nitrogen and total phosphorus in natural waters. Mar Chem 10:109-122

- Wagner F, Gimona M, Ahorn H, Peschek GA, Falkner G (1994) Isolation and functional reconstitution of a phosphate binding protein of the cyanobacterium Anacystis nidulans induced during phosphate-limited growth. J Biol Chem 269:5509-5511

> Wagner F, Falkner R, Falkner G (1995) Information about previous phosphate fluctuations is stored via an adaptive response of the high-affinity phosphate uptake system of the cyanobacterium Anacystis nidulans. Planta 197: 147-155

Wagner F, Sahan E, Falkner G (2000) The establishment of coherent phosphate uptake behaviour by the cyanobacterium Anacystis nidulans. Eur J Phycol 35:243-253

Submitted: May 30, 2012; Accepted: August 28, 2012

Proofs received from author(s): October 29, 2012 